\title{
Effect of Pre Harvest Spray of Different Forms of Calcium on Post-Harvest Quality of Guava cv. Allahabad Safeda
}

\author{
N. U. Vani*, A. Bhagwan, A. Kiran Kumar and M. Sreedhar \\ ${ }^{1}$ Department of Horticulture with Specialization in Fruit Science, \\ College of Horticulture, Rajendranagar, India \\ ${ }^{2}$ Fruit Research Station, Sangareddy, India \\ ${ }^{3}$ College of Horticulture, Rajendranagar, Hyderabad, India \\ ${ }^{4}$ Department of Genetics and Plant breeding MFPI Quality Control Laboratory, \\ PJTSAU, Rajendranagar, Hyderabad, India \\ *Corresponding author
}

\section{A B S T R A C T}

\section{Keywords}

Hasth bahar, calcium nitrate, calcium sulphate, calcium chloride, quality

\section{Article Info}

Accepted:

05 June 2020

Available Online:

10 July 2020
An experiment entitled "Effect pre harvest spray of different forms of calcium $\left(\mathrm{CaCl}_{2}\right.$, $\mathrm{Ca}\left(\mathrm{NO}_{3}\right)_{2}, \mathrm{CaSO}_{4}$ each at 1 and $2 \%$ ) on post-harvest quality of guava cv. Allahabad Safeda was conducted under randomized block design during the period of July, 2018 to January, 2019 at Fruit research station, Sangareddy, SKLTSHU, Telangana. The different levels of calcium had significant influence on the quality parameters. Various physical parameters like fruit length $(\mathrm{cm})$, fruit diameter $(\mathrm{cm})$, fruit weight $(\mathrm{g})$, fruit firmness $\left(\mathrm{kg} / \mathrm{cm}^{2}\right)$, shelf life (days), PLW(\%), spoilage $(\%)$ and bio-chemical parameters like TSS ( ${ }^{\circ}$ Brix $)$, ascorbic acid $(\mathrm{mg} / 100 \mathrm{~g})$, titrable acidity $(\%)$, total sugars $(\%)$, reducing sugars $(\%)$, non- reducing sugars $(\%)$ and Brix: Acid ratio were recorded. Among different forms of pre-harvest sprays of calcium, $\mathrm{Ca}\left(\mathrm{NO}_{3}\right)_{2} @$ $2 \%$ has recorded significantly the highest total soluble solids (11.39 $\left.{ }^{\circ} \mathrm{B}\right)$, ascorbic acid $(159.49 \mathrm{mg} / 100 \mathrm{~g})$, total sugars $(9.00 \%)$, reducing sugars $(5.23 \%)$, non-reducing sugars $(3.78 \%)$, TSS: Acid ratio (31.08), fruit firmness $\left(10.03 \mathrm{~kg} / \mathrm{cm}^{2}\right)$, shelf life (8.51days) when compared to control. The same treatment recorded minimum acidity $(0.37 \%)$, PLW (11.63\%) and spoilage percentage $(62.86 \%)$. $\mathrm{Ca}\left(\mathrm{NO}_{3}\right)_{2} @ 2 \%$ emerged as best treatment to improve the quality attributes of guava cv. Allahabad Safeda.

\section{Introduction}

Guava (Psidium guajava L.) the apple of the tropics, is one of the most popular fruits grown in tropical, sub-tropical and some parts of arid regions of India. The fruit belongs to the family Myrtaceae. Due to hardy nature of plant it can withstand adverse climatic conditions and grows under a wide range of soil types from sandy loam to clay loam (Dhaliwal and Singla 2002). Guava is a prolific bearer and highly remunerative even without much care. Therefore, it is an ideal fruit crop in terms of yield, nutritional security as well as in economic boost. In India, guava position in production is fifth 
after Banana, Mango, Citrus and Papaya (Anonymous, 2017-18). Winter guava is mostly preferred in India which gives flowering in June-July and comes to harvest during Nov - Dec.

Guava has gained the considerable prominence due to its excellent flavor, nutritive value and pectin content and used in processing industry for preparing many kinds of excellent products like jelly, jam, canned fruit products, fruit butter, toffee, and cheese and guava nectar. It is a rich and cheap source of vitamin C and pectin (Agnihotri et al., 1962). It is also a good source of vitamin A, phosphorous, calcium and iron as well as thiamin and niacin. Further, guava fruit has effective antioxidant properties due to presence of vitamin $\mathrm{C}$ and phytonutrients such as carotenoids, isoflavonoids and polyphenols. In some countries, the leaves are used for dyeing and tanning. It has a great demand as table fruit, as raw material for the processing industries and also earns good foreign exchange (Purseglove, 1974).Leaves of guava also have some medicinal properties. The guava leaf juice provides relief from cold, cough, diarrhoea and the leaf extract is used for the treatment of epilepsy, cholera and besides its usage as dying and tanning in industries.

Pre-harvest calcium spray is one of the most important practices of new strategies applied in the integrated fruit production systems, improving fruit characteristics and minimizing fungicides sprays towards the end of the harvest period, since they improve fruit resistance to brown rot (Conway et al., 1994). Calcium, as a constituent of the cell wall, plays an important role in forming crossbridges, which influence cell wall strength and regarded as the last barrier before cell separation. It also protects membranes from disorganization and maintains protein synthesizing cells. Calcium compounds extend the shelf-life of several fruits by maintaining firmness minimizing the rate of respiration, protein breakdown and disease incidence (Conway and Sams, 1985).

Quality as well as storability of guava fruits depend much on pre-harvest treatments rather than post-harvest treatments because fruits are perishable and its post-harvest handling becomes difficult. Foliar application of nutrients has gained much importance than soil application which becomes unavailable due to complex reactions in soil and leaching losses. However, the experimental effect of calcium sprays was not studied systematically and research is meagre in guava.

Post-harvest losses are due to poor postharvest management. Post-harvest dipping will not be feasible as post-harvest handling of guava becomes difficult. Many works have been carried out with different forms of calcium in guava but not been able to standardize the best form of calcium spray in guava. So the present investigation was formulated.

\section{Materials and Methods}

An experiment was carried out during July, 2018 to January, 2019 (Hasta bahar crop) at Fruit Research Station (FRS), Sangareddy, SKLTSHU, Telangana. This experiment was laid out in randomized block design with 3 replications and 7 treatments.

Experiment was conducted on the Effect of pre harvest spray of different forms of calcium on post-harvest quality of guava (Psidium guajava L.) cv. Allahabad Safeda. Allahabad safeda was chosen for calcium sprays as its shelf life is lesser than Lucknow49. Four and half years old, well grown, uniform statured trees of guava cv. Allahabad Safeda were selected for experiment. The trees were spaced at $2.5 \mathrm{~m}$ on either side. 
Treatmental trees were selected by random numbers and the experiment was laid out in randomised block design with different treatments (Oliver, 1965).

To prepare $1 \%$ and $2 \%$ Calcium chloride, Calcium nitrate and Calcium sulphate solutions, $20 \mathrm{gm}$ and $40 \mathrm{gm}$ of each chemical was dissolved in 2 litres of water. Pre harvest sprays of different forms of calcium taken one and half month before harvesting (September) by using hand sprayer.

Random selection of trees per plots for recording the post-harvest quality characters like TSS ( ${ }^{\text {Brix }), ~ a s c o r b i c ~ a c i d ~}(\mathrm{mg} / 100 \mathrm{~g})$, titrable acidity $(\%)$, total sugars $(\%)$, reducing sugars $(\%)$, non- reducing sugars $(\%)$ and Brix: Acid ratio, fruit firmness $\left(\mathrm{kg} / \mathrm{cm}^{2}\right)$, shelf life (days), PLW(\%), spoilage $(\%)$ were recorded. Data recorded on growth, yield and quality parameter was subjected to analysis of variance (ANOVA, $\mathrm{p} \leq 0.05$ ) and means comparisons were done at $P \leq 0.05$.

\section{Results and Discussion}

\section{Total sugars}

The per cent total sugars in fruit pulp of guava cv. Allahabad Safeda as influenced by different forms of calcium were calculated and the data are presented in Table-1

Irrespective of treatments, all the forms of calcium sprayed at various concentrations exerted a significant influence on per cent total sugars. The maximum total sugars (9.00) were noticed in fruits obtained from the plants sprayed with $\mathrm{Ca}\left(\mathrm{NO}_{3}\right)_{2}$ @ $2 \%$ which was statistically on par with $\mathrm{Ca}\left(\mathrm{NO}_{3}\right)_{2} @ 1 \%$ (8.87), followed by $\mathrm{CaCl}_{2} @ 2 \%$ (8.25) which was statistically on par with $\mathrm{CaCl}_{2} @ 1 \%$ (8.01). However, the fruits harvested from plant sprayed with water (control) recorded the lowest per cent total sugars (7.16).
The present results were found similar with the findings of Alila and Achumi (2012), Kaul et al., (2009) and Haq et al., (2013) in litchi, Bhat et al., (1997) in cherry. In guava, similar results were found by Singh and Chauhan (1982), Farag and Kassem (2000), Chandra (2004), Brahmachari et al., (1997) and Jayachandran et al., (2005).

In the present investigation, calcium treated fruits maintained significantly higher level of total sugars in guava fruits. The increase in total sugars during storage might be attributed to physiological loss in weight of fruits and partly to hydrolysis of cell wall polysaccharides (Hulme, 1970). The increased conversion of starch into sugars due to activation of hydrolytic enzymes by calcium could be responsible for increase in sugar content (Saha et al., 1993). The application of different forms of calcium may have favorably influenced the metabolic activities possibly due to their increased endogenous level following external application. These may have enhanced the process of synthesis, translocation and accumulation of quality constituents like total soluble solids, sugars, TSS: acid ratio ascorbic acid following strong source sink relationship.

\section{Reducing sugars}

The per cent reducing sugars in fruit pulp of guava cv. Allahabad Safeda as influenced by different forms of calcium were calculated and the data are presented in Table-1

Irrespective of treatments, all the forms of calcium sprayed at various concentrations exerted a significant influence on per cent reducing sugars. The maximum reducing sugars (5.23) were noticed in fruits obtained from the plants sprayed with $\mathrm{Ca}\left(\mathrm{NO}_{3}\right)_{2} @ 2 \%$ followed by $\mathrm{Ca}\left(\mathrm{NO}_{3}\right)_{2} @ 1 \%(5.19), \mathrm{CaSO}_{4} @$ 2\%(4.85), $\mathrm{CaCl}_{2} @ 2 \%$ (4.77) respectively. 
However, the fruits harvested from plant sprayed with water (control) recorded the lowest reducing sugars (4.25).

The present results were found similar with the findings of Alila and Achumi (2012), Kaul et al., (2009) and Haq et al., (2013) in litchi, Bhat et al., (1997) in cherry. In guava, similar results were found by Singh and Chauhan (1982), Farag and Kassem (2000), Chandra (2004), Brahmachari et al., (1997) and Jayachandran et al., (2005).

In the present investigation, the increase in reducing sugars during storage might be attributed to physiological loss in weight of fruits and partly to hydrolysis of cell wall polysaccharides (Hulme, 1970). The increased conversion of starch into sugars due to activation of hydrolytic enzymes by calcium could be responsible for increase in sugar content (Saha et al., 1993).

\section{Non-reducing sugars}

The per cent non-reducing sugars in fruit pulp of guava cv. Allahabad Safeda as influenced by different forms of calcium were calculated and the data are presented in Table-1

Irrespective of treatments, all the forms of calcium sprayed at various concentrations exerted a significant influence on per cent non-reducing sugars. The maximum nonreducing sugars (3.78) were noticed in fruits obtained from the plants sprayed with $\mathrm{Ca}\left(\mathrm{NO}_{3}\right)_{2} @ 2 \%$ which was statistically on par with $\mathrm{Ca}\left(\mathrm{NO}_{3}\right)_{2} @ 1 \%$ (3.68) and also with $\mathrm{CaCl}_{2} @ 1 \%$ (3.54) followed by $\mathrm{CaCl}_{2} @ 2 \%$ (3.48). However, the fruits harvested from plants sprayed with water (control) recorded the lowest per cent non-reducing sugars (2.92). The present results were found similar with the findings of Alila and Achumi (2012), Kaul et al., (2009) and Haq et al., (2013) in litchi, Bhat et al., (1997) in cherry. In guava, similar results were found by Singh and Chauhan (1982), Farag and Kassem (2000), Chandra (2004), Brahmachari et al., (1997) and Jayachandran et al., (2005).

In the present investigation, the increase in non-reducing sugars during storage might be attributed to physiological loss in weight of fruits and partly to hydrolysis of cell wall polysaccharides (Hulme, 1970). The increased conversion of starch into sugars due to activation of hydrolytic enzymes by calcium could be responsible for increase in sugar content (Saha et al., 1993).

\section{TSS ( ${ }^{\circ}$ Brix)}

The data revealed that there was significant difference among different forms of calcium with respect to TSS, were calculated and the data are presented in Table-1

Irrespective of treatments, all the forms of calcium sprayed at various concentrations exerted a significant influence on TSS. The maximum TSS (11.39) was noticed in fruits obtained from the plants sprayed with $\mathrm{Ca}\left(\mathrm{NO}_{3}\right)_{2} @ 2 \%$ followed by $\mathrm{Ca}\left(\mathrm{NO}_{3}\right)_{2} @ 1 \%$ (11.23), $\mathrm{CaCl}_{2} @ 2 \%$ (10.55), $\mathrm{CaCl}_{2} @ 1 \%$ (10.14) respectively. However, the fruits harvested from plant sprayed with water (control) recorded the lowest TSS (8.09).

The present results were found similar with the findings of Alila and Achumi (2012), Kaul et al., (2009) and Haq et al., (2013) in litchi, Bhat et al., (1997) in cherry. In guava, similar results were found by Chandra et al., (1994), Singh and Chauhan (1982), Farag and Kassem (2000), Chandra (2004), Brahmachari et al., (1997) and Jayachandran et al., (2005).

In the present investigation, the increase of TSS during storage might be due to the breakdown of complex polymer into simple substances by hydrolytic enzymes and also 
due to rapid mobilization of sugars and other soluble solids to developing fruits. Higher T.S.S. induced by calcium treatments may be due to lesser utilization of sugars in metabolic processes as a result of reduced respiration (Gupta et al., 1980).

\section{Titrable acidity (\%)}

The data revealed that there was significant difference among different forms of calcium with respect to acidity, were calculated and the data are presented in Table-1.

Irrespective of treatments, all the forms of calcium sprayed at various concentrations exerted a significant influence on acidity.

The minimum acidity (0.37) was noticed in fruits obtained from the plants sprayed with $\mathrm{Ca}\left(\mathrm{NO}_{3}\right)_{2} @ 2 \%$, followed by $\mathrm{Ca}\left(\mathrm{NO}_{3}\right)_{2} @$ 1\%(0.43), $\mathrm{CaCl}_{2} @ 2 \%(0.44), \mathrm{CaCl}_{2} @ 1 \%$ (0.54). However, the fruits harvested from plant sprayed with water (control) recorded the maximum acidity (0.63).

The present results obtained in the present study are in conformity with those reported earlier by Haq et al., (2013) in litchi, Bhat et al., (1997) in cherry, Singh and Chauhan (1982) and Farag and Kassem (2000) in guava.

In the present investigation, the decrease in acidity could be explained on the grounds that organic acids might be utilized rapidly in respiration from pre-climacteric to postclimacteric stage. It may be also due to marked increase in malic enzyme and pyruvate decarboxylation reaction during the climacteric period commensurate with an increase in the rate of respiration and other biodegradable metabolic reactions (Kliewer, 1971). Neutralization of organic acids in fruit tissues could also resulted in a reduction of titrable acidity.

\section{Brix acid ratio}

The data revealed that there was significant difference among different forms of calcium with respect to brix acid ratio, were calculated and the data are presented in Table-1

Irrespective of treatments, all the forms of calcium sprayed at various concentrations exerted a significant influence on Brix acid ratio. The maximum Brix acid ratio (31.08) was noticed in fruits obtained from the plants sprayed with $\mathrm{Ca}\left(\mathrm{NO}_{3}\right)_{2} @ 2 \%$ followed by $\mathrm{Ca}\left(\mathrm{NO}_{3}\right)_{2} @ 1 \%(25.91), \mathrm{CaCl}_{2} @ 2 \%$ (23.81) respectively. However, the fruits harvested from plant sprayed with water (control) recorded the lowest Brix acid ratio (12.86).

The present results obtained in the present study are in conformity with those reported earlier by Haq et al., (2013) in litchi, Bhat et al., (1997) in cherry, Agrawal (2012), Kaul et al., (2009) and Aly and Ismail (2000) in guava.

In the present investigation, increase in Brix acid ratio might be due to increase in total soluble content of fruits with decreased acidity ultimately by pre harvest spray of calcium compounds leads to higher ratio of brix : acid.

\section{Ascorbic acid (mg/ 100g)}

The data revealed that there was significant difference among different forms of calcium with respect to ascorbic acid, were calculated and the data are presented in Table-1

Irrespective of treatments, all the forms of calcium sprayed at various concentrations exerted a significant influence on ascorbic acid. The maximum ascorbic acid (159.49) was noticed in fruits obtained from the plants sprayed with $\mathrm{Ca}\left(\mathrm{NO}_{3}\right)_{2} @ 2 \%$, followed by $\mathrm{Ca}\left(\mathrm{NO}_{3}\right)_{2} @ 1 \% \quad(157.39)$ which was 
statistically on par with $\mathrm{CaCl}_{2} @ 2 \%$ (154.73). However, the fruits harvested from plant sprayed with water (control) recorded the lowest ascorbic acid (135.38).

Results obtained regarding ascorbic acid content are in conformity with Aly and Ismail (2000) in guava, Bisen et al., (2011) and Kumar et al., (2005) in mango, Ali et al., (2014) in guava, Asghar et al., (2009) in pomegranate.

In the present investigation, increase in ascorbic acid was observed by pre- and postharvest application of calcium. The application of different forms of calcium may have favorably influenced the metabolic activities possibly due to their increased endogenous level following external application. These may have enhanced the process of synthesis, translocation and accumulation of quality constituents like total soluble solids, sugars, TSS: acid ratio ascorbic acid following strong source sink relationship. This higher retention of Vitamin $\mathrm{C}$ during storage by application of calcium might be due to continued synthesis of its precursor like Glucose-6-phosphate during conversion as starch into various sugars and slow rate of oxidation as has been reported in guava (Singh et al., 1981; Soppin et al., 1997) and in peach (Gupta et al., 1984).

\section{Fruit firmness $\left(\mathrm{kg} / \mathrm{cm}^{2}\right)$}

The data revealed that there was significant difference among different forms of calcium with respect to fruit firmness, were calculated and the data are presented in Table-1

Irrespective of treatments, all the forms of calcium sprayed at various concentrations exerted a significant influence on fruit firmness. The maximum fruit firmness (10.03) was noticed in fruits obtained from the plants sprayed with $\mathrm{Ca}\left(\mathrm{NO}_{3}\right)_{2} @ 2 \%$ followed by $\mathrm{Ca}\left(\mathrm{NO}_{3}\right)_{2} @ 1 \%$ (9.83) which was statistically on par with $\mathrm{CaCl}_{2} @ 2 \%$ (9.75). However, the fruits harvested from plant sprayed with water (control) recorded the lowest fruit firmness (7.19).

Martinsson et al., (2006) also observed that application of calcium nitrate in Elsanta Strawberry contributed to more firmness of the fruits. These findings are in line with those reported by Gupta et al., 1980 in grapes, Sudha et al., 2006 in sapota fruit, Goutam et al., (2010) in guava, Barwal et al., (2015) in apple, Raja et al., (2015) in peach, Mahajan and Sharma (2000) in pear, Gamal (2012) in apricot, Saran et al., (2004) in ber

In the present investigation, Calcium is essential for the firmness of cell membrane systems on which the fundamental integrity of the cell metabolism is dependent. The fruit firmness has direct relationship with pectin content which was primarily due to higher calcium content of fruits. Calcium having profound effect on the cell wall (Goutam et al., 2010) reported that calcium compounds significantly thickened the middle lamella of fruit cells owing to increased deposition of calcium pectate and thereby maintained the cell wall. According to Faust and Shear (1972), calcium was effective in increasing the firmness of fruits by delaying senescence, preserving cellular organization and retarding respiration rate. Thus, calcium treated fruits recorded significantly higher firmness.

\section{Shelf life (days)}

The data revealed that there was significant difference among different forms of calcium with respect to shelf life, were calculated and the data are presented in Table-1

Irrespective of treatments, all the forms of calcium sprayed at various concentrations exerted a significant influence on shelf life. 
The maximum shelf life (8.51) was noticed in fruits obtained from the plants sprayed with $\mathrm{Ca}\left(\mathrm{NO}_{3}\right)_{2} @ 2 \%$, followed by $\mathrm{Ca}\left(\mathrm{NO}_{3}\right)_{2} @$ $1 \%(8.08)$ which was statistically on par with $\mathrm{CaCl}_{2} @ 2 \%$ (7.84). However, the fruits harvested from plant sprayed with water (control) recorded the lowest shelf life (7.19).

Calcium nitrate at $2 \%$ has significantly influenced shelf life of guava cv. Allahabad Safeda. Similar results obtained by Goutam et al., (2010), Singh et al., (1981), Jayachandran et al., (2005) in guava, Bharathi and Srihari (2004) in sapota and Mahajan et al., (2008) in plum. Singh et al., (2007) reported that spray of calcium nitrate at lower concentration i.e., $1.0 \%$ also showed beneficial effects in prolonging the storage life of guava fruits upto 10 days in cv. Allahabad Safeda. More shelf life about 10days was observed when guava fruits are sprayed with calcium nitrate at $1 \%$ (Ali et al., 2014). Calcium proved beneficial in delaying the ripening related changes in guava fruits (Deepthi et al., 2016). The present results are similar with the findings of Bhusan and Panda (2015) in Amrapali and Singh et al., (2012) in Dashehari mango.

In the present investigation, shelf life increased with calcium sprays might be due to the fact that calcium, as a constituent of the cell wall, plays a important role in forming cross- bridges, which influence cell wall strength and regarded as the last barrier before cell separation. Calcium spray during fruit development provides a safe mode of supplementing endogenous calcium to fresh fruits. Calcium having profound effect on the cell wall (Goutam et al., 2010) reported that calcium compounds significantly thickened the middle lamella of fruit cells owing to increased deposition of calcium pectate and thereby maintained the cell wall. Thus, calcium decreased the spoiling of fruit by reduction in process of respiration and increased the fruit firmness which lead to benefits like slower ripening and increased the shelf life (Karemera and Habimana, 2014).

\section{Physiological loss in weight (\%)}

The data revealed that there was significant difference among different forms of calcium with respect to PLW, were calculated and the data are presented in Table-2. Irrespective of treatments, all the forms of calcium sprayed at various concentrations exerted a significant influence on PLW.

The lowest PLW @ 3days (3.87) was noticed in fruits obtained from the plants sprayed with $\mathrm{Ca}\left(\mathrm{NO}_{3}\right)_{2} @ 2 \%$, followed by $\mathrm{Ca}\left(\mathrm{NO}_{3}\right)_{2} @$ 1\%(4.06), $\mathrm{CaCl}_{2} @ 2 \%$ (4.30), $\mathrm{CaCl}_{2} @ 1 \%$ (4.77) respectively. However, the fruits harvested from plant sprayed with water (control) recorded the maximum PLW @ 3days (7.08).

The lowest PLW @6 days (7.36)was noticed in fruits obtained from the plants sprayed with $\mathrm{Ca}\left(\mathrm{NO}_{3}\right)_{2} @ 2 \%$, followed by $\mathrm{Ca}\left(\mathrm{NO}_{3}\right)_{2} @$ $1 \%(7.48), \mathrm{CaCl}_{2} @ 2 \%$ (7.72) respectively, and statistically on par with $\mathrm{CaCl}_{2} @ 1 \%$ (7.75). However, the fruits harvested from plant sprayed with water (control) recorded the maximum PLW @ 6days (11.11).

The lowest PLW @ 9days (11.63) was noticed in fruits obtained from the plants sprayed with $\mathrm{Ca}\left(\mathrm{NO}_{3}\right)_{2} @ 2 \%$, followed by $\mathrm{Ca}\left(\mathrm{NO}_{3}\right)_{2} @ 1 \%$ (11.94), $\mathrm{CaCl}_{2} @ 1 \%$ (12.83), $\mathrm{CaCl}_{2} @ 2 \%$ (13.26) respectively. However, the fruits harvested from plant sprayed with water (control) recorded the maximum PLW @ 9days (20.68). The role of calcium chloride in reducing physiological loss in weight has been reported by Singh and Chauhan (1982), Mishra et al., (2003) and Jaychandran et al., (2005) in guava are in conformity with the present results. Kirmani 
et al., (2013) also reported the $\mathrm{CaCl}_{2}$ is the most effective in 15 days storage of plum for minimizing physiological loss in weight. Similar results on reductions in weight loss by calcium treatment were also reported by Gupta et al., (1987) and Saran et al., (2004) in ber, Ghosh et al., (2003) in litchi, Ramkrishna et al., (2001) in papaya.

In the present investigation, the decrease in weight loss by application of calcium might be due to its role in the maintenance of the fruits firmness (Mika, 1983), retardation of respiratory rate (Jones et al., 1967) and delayed senescence (Bangerth et al., 1972).

The possible reason for reduced weight loss by chemicals may be due to some chemical changes within the fruits, resulting in retention of more water against the rate of evaporation. This may be due to the role of calcium on limiting respiration which was attributed to altered membrane permeability (Conway and sams, 1985).

\section{Spoilage (\%)}

The data revealed that there was significant difference among different forms of calcium with respect to spoilage percentage, were calculated and the data are presented in Table2. Irrespective of treatments, all the forms of calcium sprayed at various concentrations exerted a significant influence on spoilage percentage.

The lowest spoilage percentage @ 6 days (22.53) was noticed in fruits obtained from the plants sprayed with $\mathrm{Ca}\left(\mathrm{NO}_{3}\right)_{2} @ 2 \%$ which was on par with $\mathrm{Ca}\left(\mathrm{NO}_{3}\right)_{2} @ 1 \%$ (25.06), followed by $\mathrm{CaCl}_{2} @ 1 \% \quad(30.43)$ which was on par with $\mathrm{CaCl}_{2} @ 2 \%$ (32.80). However, the fruits harvested from plant sprayed with water (control) recorded the maximum spoilage percentage @ 6days (44.73). The lowest spoilage percentage @ 9days (62.86) was noticed in fruits obtained from the plants sprayed with $\mathrm{Ca}\left(\mathrm{NO}_{3}\right)_{2} @ 2 \%$, followed by $\mathrm{Ca}\left(\mathrm{NO}_{3}\right)_{2} @ 1 \%$ (67.49) which was on par with $\mathrm{CaCl}_{2} @ 2 \%$ (68.44), followed by $\mathrm{CaCl}_{2} @ 1 \%$ (71.44) respectively. However, the fruits harvested from plant sprayed with water (control) recorded the maximum spoilage percentage @ 9days (87.62).

Gupta et al., (1984) reported that calcium compounds significantly thickened the middle lamella of fruit cells owing to increased deposition of calcium pectate and thereby maintained the cell wall, which inhibits the penetration and spread of pathogens in fruits ultimately reducing the spoilage percentage in peach fruits. Our results are in concordance with the findings of Hiwale and Singh (2003), Selvan and Bal (2005) and Goutam et al., (2010) in guava fruits, Conway et al., (1994), Mahajan and Sharma (2000) in pear, Mir et al., (1996) in apple, Saran et al., (2004) in ber.

In the present investigation, improved resistance to spoilage in calcium-treated fruit was associated with preservation of cell wall and middle lamella structure. This might be due to higher firmness of fruit which inhibits the penetration and spread of pathogens in fruits (Gupta et al., 1987). Calcium maintains the structural rigidity of cell wall and thereby reduces the penetration of Rhizopus rot/soft rot causing organisms like fungi and bacteria, which transform parenchymatous tissue to watery mass. Calcium also imparts resistance against certain pathogenic invasion (Bangreth et al., 1972) and has been associated with decreased incidences of physiological disorders, improved storage life and reduced severity of bacterial and fungal decay (Conway and Sams, 1985). The higher spoilage in untreated fruits was the result of lesser tissue strength and cellular disorganization of the cell organelle. 
Table.1 Effect of pre harvest spray of different forms of calcium on total sugars, reducing and non-reducing sugars, TSS, acidity and Brix Acid ratio, ascorbic acid, fruit firmness and shelf life of guava cv. Allahabad Safeda

\begin{tabular}{|c|c|c|c|c|c|c|c|c|c|}
\hline TREATMENTS & $\begin{array}{l}\text { Total } \\
\text { sugars } \\
(\%)\end{array}$ & $\begin{array}{l}\text { Reducing } \\
\text { sugars } \\
(\%)\end{array}$ & $\begin{array}{l}\text { Non- } \\
\text { reducing } \\
\text { sugars } \\
(\%)\end{array}$ & $\begin{array}{c}\text { TSS } \\
\left({ }^{\circ} \text { Brix }\right)\end{array}$ & $\begin{array}{l}\text { Titrable } \\
\text { acidity } \\
(\%)\end{array}$ & $\begin{array}{l}\text { Brix } \\
\text { acid } \\
\text { ratio }\end{array}$ & $\begin{array}{l}\text { Ascorbi } \\
\text { c acid } \\
\text { (mg/ } \\
\text { 100g) }\end{array}$ & $\begin{array}{l}\text { Fruit } \\
\text { firmness } \\
\left(\mathrm{kg} / \mathrm{cm}^{2}\right)\end{array}$ & $\begin{array}{l}\text { Shelf } \\
\text { life } \\
\text { (days) }\end{array}$ \\
\hline $\mathrm{T}_{1}-\mathrm{CaCl}_{2} @ 1 \%$ & $8.01^{b}$ & $4.47^{b}$ & $3.54^{\mathrm{c}}$ & $10.14^{\mathrm{d}}$ & $0.54^{\mathrm{d}}$ & $18.67^{\mathrm{d}}$ & $147.69^{b}$ & $9.19^{c}$ & $7.52^{c}$ \\
\hline $\mathrm{T}_{2}-\mathrm{CaCl}_{2} @ \mathbf{2 \%}$ & $8.25^{\mathrm{b}}$ & $4.77^{\mathrm{d}}$ & $3.48^{\mathrm{b}}$ & $10.55^{\mathrm{e}}$ & $0.44^{\mathrm{c}}$ & $23.81^{\mathrm{e}}$ & $154.73^{c}$ & $9.75^{\mathrm{d}}$ & $7.84^{\mathrm{d}}$ \\
\hline $\mathrm{T}_{3}-\mathrm{Ca}\left(\mathrm{NO}_{3}\right)_{2} @ 1 \%$ & $8.87^{\mathrm{c}}$ & $5.19^{f}$ & $3.68^{\mathrm{c}}$ & $11.23^{\mathrm{f}}$ & $0.43^{\mathrm{b}}$ & $25.91^{\mathrm{f}}$ & $157.39^{c}$ & $9.83^{\mathrm{d}}$ & $8.08^{\mathrm{d}}$ \\
\hline $\mathrm{T}_{4}-\mathrm{Ca}\left(\mathrm{NO}_{3}\right)_{2} @ 2 \%$ & $9.00^{c}$ & $5.23^{g}$ & $3.78^{\mathrm{c}}$ & $11.39^{\mathrm{g}}$ & $0.37^{\mathrm{a}}$ & $31.08^{\mathrm{g}}$ & $159.49^{d}$ & $10.03^{\mathrm{e}}$ & $8.51^{\mathrm{e}}$ \\
\hline $\mathrm{T}_{5}-\mathrm{CaSO}_{4} @ 1 \%$ & $7.85^{\mathrm{a}}$ & $4.74^{c}$ & $3.11^{\mathrm{a}}$ & $9.95^{\mathrm{c}}$ & $0.55^{\mathrm{e}}$ & $17.99^{c}$ & $141.86^{\mathrm{b}}$ & $8.43^{b}$ & $6.54^{\mathrm{a}}$ \\
\hline $\mathrm{T}_{6}-\mathrm{CaSO}_{4} @ 2 \%$ & $7.90^{\mathrm{b}}$ & $4.85^{\mathrm{e}}$ & $3.05^{\mathrm{a}}$ & $9.74^{b}$ & $0.58^{f}$ & $16.80^{b}$ & $139.12^{b}$ & $8.40^{\mathrm{b}}$ & $6.65^{b}$ \\
\hline $\mathbf{T}_{7}$ - Control & $7.16^{\mathrm{a}}$ & $4.25^{\mathrm{a}}$ & $2.92^{\mathrm{a}}$ & $8.09^{\mathrm{a}}$ & $0.63^{\mathrm{g}}$ & $12.86^{\mathrm{a}}$ & $135.38^{\mathrm{a}}$ & $7.19^{\mathrm{a}}$ & $6.32^{\mathrm{a}}$ \\
\hline S.E m \pm & 0.22 & 0.006 & 0.09 & 0.07 & 0.002 & 0.098 & 1.14 & 0.04 & 0.09 \\
\hline $\mathrm{CD}(\mathrm{P}=0.05)$ & 0.69 & 0.019 & 0.28 & 0.02 & 0.006 & 0.306 & 3.55 & 0.13 & 0.28 \\
\hline
\end{tabular}

Table.2 Effect of pre harvest spray of different forms of calcium on Physiological loss in weight (\%) Spoilage percentage (\%) of guava cv. Allahabad Safeda

\begin{tabular}{|c|c|c|c|c|c|c|c|c|}
\hline \multirow[b]{2}{*}{ TREATMENTS } & \multicolumn{4}{|c|}{ Physiological loss in weight (\%) } & \multicolumn{4}{|c|}{ Spoilage percentage $(\%)$} \\
\hline & 0 days & 3 days & 6 days & 9 days & 0 days & 3 days & 6 days & 9 days \\
\hline $\mathrm{T}_{1}-\mathrm{CaCl}_{2} @ 1 \%$ & 0 & $4.77^{\mathrm{d}}$ & $7.72^{c}$ & $12.83^{\mathrm{c}}$ & 0 & 0 & $30.43^{\mathrm{b}}$ & $71.44^{\mathrm{c}}$ \\
\hline $\begin{array}{l}\mathbf{T}_{2}-\mathbf{C a C l}_{2} @ \\
2 \%\end{array}$ & 0 & $4.30^{\mathrm{c}}$ & $7.75^{\mathrm{c}}$ & $13.26^{\mathrm{d}}$ & 0 & 0 & $32.80^{\mathrm{b}}$ & $68.44^{\mathrm{b}}$ \\
\hline $\begin{array}{l}\mathrm{T}_{3}-\mathrm{Ca}\left(\mathrm{NO}_{3}\right)_{2} \\
@ 1 \%\end{array}$ & 0 & $4.06^{\mathrm{b}}$ & $7.48^{\mathrm{b}}$ & $11.94^{\mathrm{b}}$ & 0 & 0 & $25.06^{\mathrm{a}}$ & $67.49^{b}$ \\
\hline $\begin{array}{l}\mathrm{T}_{4}-\mathrm{Ca}\left(\mathrm{NO}_{3}\right)_{2} \\
@ 2 \%\end{array}$ & 0 & $3.87^{\mathrm{a}}$ & $7.36^{\mathrm{a}}$ & $11.63^{\mathrm{a}}$ & 0 & 0 & $22.53^{\mathrm{a}}$ & $62.86^{\mathrm{a}}$ \\
\hline $\begin{array}{l}\mathrm{T}_{5}-\mathrm{CaSO}_{4} @ 1 \\
\%\end{array}$ & 0 & $5.11^{\mathrm{f}}$ & $8.47^{\mathrm{d}}$ & $14.49^{f}$ & 0 & 0 & $33.78^{c}$ & $80.68^{\mathrm{e}}$ \\
\hline $\begin{array}{l}\mathrm{T}_{6}-\mathrm{CaSO}_{4} @ 2 \\
\%\end{array}$ & 0 & $4.86^{\mathrm{e}}$ & $9.18^{\mathrm{e}}$ & $13.44^{\mathrm{e}}$ & 0 & 0 & $41.11^{\mathrm{d}}$ & $73.49^{\mathrm{d}}$ \\
\hline $\mathbf{T}_{7}$ - Control & 0 & $7.08^{\mathrm{g}}$ & $11.11^{\mathrm{f}}$ & $20.68^{\mathrm{g}}$ & 0 & 0 & $44.73^{\mathrm{e}}$ & $87.62^{f}$ \\
\hline S.E m \pm & 0 & 0.016 & 0.02 & 0.05 & 0 & 0 & 1.01 & 0.46 \\
\hline $\mathrm{CD}(\mathrm{P}=\mathbf{0 . 0 5})$ & 0 & 0.051 & 0.06 & 0.15 & 0 & 0 & 3.14 & 1.43 \\
\hline
\end{tabular}

Among different forms of pre-harvest sprays of calcium, $\mathrm{Ca}\left(\mathrm{NO}_{3}\right)_{2} @ 2 \%$ has recorded significantly maximum total soluble solids, ascorbic acid total sugars, reducing sugars, non-reducing sugars, TSS: Acid ratio, fruit firmness, shelf life when compared to control. Same treatment recorded minimum acidity
$(\%)$, PLW and spoilage percentage. From the results obtained in the present investigation, it can be concluded that $\mathrm{Ca}\left(\mathrm{NO}_{3}\right)_{2} @ 2 \%$ emerged as best treatment to improve the quality attributes of guava cv. Allahabad Safeda. 


\section{Acknowledgement}

The work was supported by department of Fruit Science, College of Horticulture, Rajendranagar, Hyderabad, India. I am thankful to Ramulu, Ratnam and Varalaxmi for their assistance in the completion of this research work.

\section{References}

Agnihotri, B. N., Kapoor, K. L., God, K. R. 1962. Guava. In: A Textbook on Pomology, Chattopadhyay TK (ed), Vol II, Kalyani Pub, New Delhi, 277p.

Ali, W., Pathak, R. A. and Yadav, A. L. 2014. Effect of foliar application of nutrients on guava (Psidium guajava L.) cv. Allahabad Safeda, Progressive Horticulture. 23(14):18-21, 1991.

Alila, P. and Achumi, I. 2012. Pre-harvest chemical treatments affect post-harvest quality of litchi fruit. Acta Horticulture. 934.

Anonymous. 2017-18. All India area and production of fruits. National Horticulture Board, Gurgaon, India. pp. 1-3.

Asghar, R., Majid, R. and Mohammad, R. V. 2009. Effects of foliar application of calcium chloride and urea on quantitative and qualitative characteristics of pomegranate fruits. Scientia Horticulturae. 121: 171-175.

Asgharzade, A. and Babaeian, M. 2012. Foliar application of calcium borate and micronutrients effect on some characters of apple fruit in shrivan region. Annals of Biological Research. 3(1): 527-533.

Awasthi, Priya and Lal, Shant. 2009. Effect of calcium, boron and zinc foliar sprays on the yield and quality of guava (Psidium guajava L.). Pantnagar. J .Res. 7(2): 223225.

Bangerth, F., Dilley, D. R. and Daway, D. H. 1972. Effect of post harvest calcium treatments on the internal breakdown and respiration of apple fruits. J. Amer. Soc. Hort. ScL. 97 (4): 679-682.

Barwal, V. S. and Gupta, B. 2015. Effect of preharvest calcium and fungicide sprays on post harvest quality and shelf life of Red Delicious apple. Journal of Hill Agriculture. 6(2): 259-263.

Barwal, V. S. and Kumar, J. 2014. Effect of preharvest calcium sprays and harvesting time on quality and shelf-life of nectarines. Advances in Applied Research. 6(1): 53-56.

Bharathi, M and Srihari, D. 2004. Effect of various calcium compounds on physicochemical attributes after harvest in sapota cv. Kalipatti. Journal of Research ANGRAU, 32(1):17-22.

Bhatt, A., Mishra, N. K., Mishra, D. S. and Singh, C. P. 2012. Foliar application of potassium, calcium, zinc and boron enhanced yield, quality and shelf life of mango. HortFlora Research Spectrum. 1(4): 300-305.

Bhatt. A. R., Sofi, A. G., Mir, M. A. and Gani, M. R. 1997. Effect of preharvest sprays of calcium and potassium on some quality characteristics of cherry cv Makhmali. Indian J. Horlt. 54(1): 19-24.

Bhusan, L. and Panda, C. 2015. Effect of preharvest chemical treatments and mulching on quality of mango, (Mangifera indica L.) cv. Amrapali fruits. International Journal of Farm Sciences. 5(4): 132-138.

Bisen, S., Jain, P. K. and Tiwari, A. 2011. Effect of foliar application of calcium nitrate and urea on yield and quality of aonla. Ind. J. of Horti. 68(4): 564-566.

Brahmachari, V. S., Kumar, N. and Kumar, R. 1997. Effect of foliar feeding of calcium, potassium and growth substance on yield and quality of guava (Psidium guajava L.). Haryana J. Hort. Sci. 26 (3-4): 169-173.

Brar, S. S., Simnani, S. S. A. and Kaundal, G. S. 1997. Effect of preharvest sprays of calcium nitrate on the storage life of Shane-Punjab Peach. Journal of Research, Punjab Agricultural University. 34(2). 174180.

Chandra, R., Govind, S. and Basuchaudhuri, P. 1994. Pre-harvest sprays of calcium nitrate and Alar on quality and post-harvest behaviour of guava fruits. Indian Journal of Hill Farming. 7 (1): 51-56

Chandra, R., Gupta, P. N. and Rajput C. B. S. 1999. Influence of pre-harvest application of calcium and alar on post-harvest changes in cv. Sardar guava fruits. Tropical 
Agriculture. 76 (1): 70-73.

Chandra, R., Manju, B., Rawat, S. S and Singh, K. K. 2015. Effect of foliar application of various growth regulators on yield and quality of aonla cv. NA-7. International Journal of Tropical Agriculture. 33(3):15862.

Chandra, S. 2004. Effect of calcium on the storage life of guava (Psidium guajava L.) M.Sc. Thesis. Chaudhary Charan Singh Haryana Agril. Univ., Haryana.

Chauhan, B. B. S., Shukla, P. K., Yadava, L. P. and Verma, D. 2014. Effect of preharvest foliar spray of $\mathrm{Ca}, \mathrm{Zn}$ and $\mathrm{B}$ on respiration rate and biochemical changes of Dashehari mango during storage. African Journal of Agricultural Marketing. 2(1): 47-55.

Conway, W. S. and Sams, C. S. 1985. Influence of fruit maturity on the effect of post-harvest calcium treatment on decay of Golden Delicious apples. Plant Res. 69:42-44.

Conway, W. S. and Sams, C. S. 1985. Influence of fruit maturity on the effect of post-harvest calcium treatment on decay of Golden Delicious apples. Plant Res. 69:42-44.

Conway, W. S., Sams, C. S. and Kelman, A. 1994. Enhancing the natural resistance of plant tissue to post-harvest diseases through calcium applications. HortSci. 29:751-161.

Conway, W. S., Sams, C. S. and Kelman, A. 1994. Enhancing the natural resistance of plant tissue to post-harvest diseases through calcium applications. HortSci. 29:751-161.

Deepthi, V. P, Chandra Sekhar, R, Srihari, D and Siva Sankar, A. 2016. Guava fruit quality and storability as influenced by harvest maturity and post-harvest application of calcium salts. Plant Archives. 16(1): 174182.

Dhaliwal, G. S. and Singla R. 2002. Studies on the time of anthesis and dehiscence in different genotypes of guava in winter and rainy season crops. Indian J Hort. 59:157-161.

Farag, K. M. and Kassem, H. A. 2000. Effect of Naphthalene Acetic Acid, Calcium, Phosphorus, or Potassium on fruit Quality, Abscission and the Shelf Life of Guava Fruits. Emir. J. Agric. Sci. 12: 01-19.

Faust, M. and Shear, C. B. 1972. The effect of calcium on respiration of apples. J. Amer. Soc. Hort. Sci. 97: 437-439.
Gamal, A. Abdrabboh. 2012. Effect of some preharvest treatments on quality of canino apricot fruits under cold storage conditions. J. of Hort. Sci. \& Ornamental pt. 4 (2): 227-234.

Ghosh, U., Bhattacharjee, A., Bose, P. K., Chowdhury, D. R., \& Gangopadhyay, H. 2003. Effect of chemical treatment on the physiochemical changes of litchi stored under modified atmosphere. The Ind. J. Nutr. Diete, 40, 447-453.

Goutam, M., Dhaliwal, H. S. and Mahajan, B.V.C. 2010. Effect of pre-harvest calcium sprays on post-harvest life of winter guava (Psidium guajava L.). J. Food Sci. and Tech. 47 (5): 501-506.

Gupta, O. P., Jindal, P. C. and Singh, B.P. 1980. Effect of pre-harvest spray of calciumnitrate on the storage behaviour of grape $\mathrm{cv}$. Perlette. J.Res. Haryana Agric.Univ. 10: 204-206.

Gupta, O. P., Siddiqui, S. and Chauhan, K. S. 1987. Evaluation of various calcium compounds for increasing the shelf life of ber (Zizyphus mauritiana Lamk) Fruits. Indian Journal of Agricultural Research, 21: 65-70.

Gupta, O. P., Singh, B. P., Singh, S. P. and Chauhan, K. S. 1984. Effect of calcium compounds as pre-harvest spray on the shelf life of peach cv. Sharbati. Punjab Hort. J. 24: 105-110.

Haq, I., Rab, A. and Sajid, M. 2013. Foliar application of calcium chloride and borax enhance the fruit quality of litchi cultivars. The Journal of Animal and plant Sciences. 23(5): 1385-1390.

Hiwale, S. S. and Singh, S. P. 2003. Prolonging the shelf-life of guava (Psidium guajava L.). Indian J Hort 60:1-9

Hulme, A. C. 1970. The biochemistry of fruits and their products. Academic Press, London and New York, p. 267-304.

Jayachandran, K. S., Srihari, D. and Reddy, Y. Narayana. 2005. Pre-harvest sprays of different sources of calcium to improve the shelf-life of guava. Indian J. of Hort. 62(1): 68-70.

Jitendra kumar., Rajesh kumar, Ratna rai and Mishra, D. S. 2015. Response of 'pant prabhat' guava trees to foliar sprays of zinc, 
boron, calcium and potassium at different plant growth stages. An International Quarterly journal of Life Sciences. 10(2): 495-498.

Jones, R., Wyn, G. and Lunt, O. R. 1967. The function of calcium in plants. Bol. fev. 33: 407-423.

Jones, R., Wyn, G. and Lunt, O. R. 1967. The function of calcium in plants. Bol. fev. 33: 407-423.

Karemera, N. U. and Habimana S. 2014. Effect of pre-harvest calcium chloride on postharvest behavior of mango fruits (Mangifera indica L.) cv. Alphonso. Universal Journal of Agricultural Research. 2(3):119-125.

Kirmani, S. N., Wani, G. M., Wani, M. S., Ghani, M. Y., Abid, M., Mujamil, S., Raja, H. and Malik, A. R. 2013. Effect of pre-harvest application of calcium chloride, Gibberlic acid and Napthelenic acetic acid on storage of plum (Prunus salicina L.) cv. Santa Rosa under ambient storage conditions. African J. of Agril. Research. 8 (9): 812-818.

Kliewer, W. M. 1971. The effect of day temperature and light intensity on concentration of malic and tartaric acids in grapes (Vitis vinifera). J Amer Soc Hort Sci 97: 372.

Kumar Raj, M., Reddy, Y.N., Chandrasekhar, R and Srihari, D. 2005. Effect of foliar application of chemicals and plant growth regulators on flowering of unpruned mango trees of cv. Baneshan. Journal of Research ANGRAU. 33: 2, 6-11.

Mahajan, B. V. C and Sharma, R. C. 2000. Effect of pre-harvest applications of growth regulators and calcium chloride on physicchemical characteristics and storage life of peach (Prunus persica) cv. Shan-e-Punjab. Haryana Journal of Horticulture Science. 29(1-2): 41-43.

Mahajan, B. V. C, Randhana, J. S, Kaur, H and Dhatt, A. S. 2008. Effect of post-harvest application of calcium nitrate and gibberllic acid on the storage life of plum. Ind. J. of Horti. 65(1):94-96.

Martinsson, M., Kwast, A., Cieslinski, G. and Treder, W. 2006. Impact of production systems and fertilizer application on yield and quality of strawberries. Acta Hort. 708: 59-64.
Mika, A. 1983. Studies on calcium penetration into apple fruits after postharvest treatment with calcium chloride. Acta Hort. 138: 1521.

Mika, A. 1983. Studies on calcium penetration into apple fruits after postharvest treatment with calcium chloride. Acta Hort. 138: 1521.

Mir, N. A., Dalal, M. A. Bhat, A. R. and Ganaie, R. D. 1996. Effect of pre-harvest spray of calcium and growth regulators on physicchemical characteristics in relation to length of storage in apple. Indian Journal of Plant Physiology. 1(1): 52-53.

Mishra, D. S., Tiwari, J. P., Misra, K. K. and Shantlal. 2003. Effect of calcium nitrate and method of application nutrient content of leaves and post-harvest quality of guava fruit. Sci. Hort. (8): 11-19.

Oliver, L. Lacey. 1965. Statistical Methods in Experimentation. 1: 11-30.

Purseglove, J. W. 1974. Tropical Crops Dicotyledons. Longman, London. pp. 20810.

Raese, J. T. and Drake, S. R. 2006. Calcium Foliar Sprays for Control of Alfalfa Greening, Cork Spot, and Hard End in 'Anjou' Pears. Journal of Plant Nutrition. 29(3): 543-552.

Raja, R. H. S., Bhat, Z. A., Malik, A. R. and Shafi, R. H. 2015. Interrelationship between fruit quality and pre-harvest calcium chloride treatment on peach cv. 'Shan-ePunjab'. International Journal of Agriculture, Environment and Biotechnology. 8(1): 103-10

Ramakrishna. M., Haribabu, K., Reddy, Y. N., Purushotham, K. 2001. Effect of preharvest application of calcium on physicochemical changes during ripening and storgae of papaya. Ind. J. of Horti. 58(3):228-231.

Raychaudhary, R., Kabir, J., Ray, S., Dutta, K. and Dhua, R. S. 1992. Influence of preharvest spray of calcium salts in the improvement of fruit quality in guava cv. L-49. Advances in Horticulture and Forestry. 2: 70-76.

Saha, D. P., Sharma, R. K., Kumar, R. and Thakur, S. 1993. Effect of preharvest application of calcium salts on fruit cracking and physico-chemical composition 
of fruits in litchi. Orissa J. Hort. 21 (1-2): 53-57.

Saran, P. L., Lal, G., Jat, R. J. and Singh, R. V. 2004. Effect of pre-harvest foliar application of different chemicals on shelf life and quality of ber (Zizyphus mauritiana Lamk) cv. Gola. Haryana Journal of Horticulture Science. 33(12): 71-73.

Selvan, M. T., Bal, J. S. 2005. Effect of different treatments on the shelflife of 'Sardar' guava during cold storage. J Res Punjab Agric Univ. 42:28-33

Sharad Bisen., Thakur, R. S. and Dharna Tembhare. 2014. Effect of calcium nitrate and gibberellic acid application on growth, fruit quality and post-harvest behaviour of guava fruit. An International Quarterly Journal of Environmental Sciences. Vol. VI: 55-62.

Sharma, R. K., Kumar, Ram and Thakur, S. 1991. Effect of foliar feeding of potassium,calcium and zinc on yield and quality of guava. Indian J. Hort. 48(4): 312-314.

Shukla, A. K. 2011. Effect of foliar application of calcium and boron on growth, productivity and quality of Indian gooseberry (Emblica officinalis). Indian J. Agricl. Sci. 81 (7): 628-632.

Siddiqui, S. and Bangerth, F. 1996. The effect of calcium infiltration on structural changes in cell walls of stored apples. Journal of Horticultural Science, 71: 703-708.

Singh, K. and Chauhan, K. S. 1982. Effect of preharvest application of calcium, potassium and Alar on fruit quality and storage life of guava fruits. Haryana J. Hort. Sci. 12 (4): 649-654.

Singh, R., Chaturvedi, O. P., Gaur, G. S. and Singh, G. 2007. Effect of pre-harvest spray of zinc, calcium and boron on the storage behaviour of guava (Psidium guajava L.) fruits cv. Allahabad safeda. ISHS Acta Hort. 735 (1): 633-638.

Singh, R., Godara, N. R., Singh, R. and Dhaiya, S. S. 2001. Response of foliar application of growth regulators and nutrients in ber (Zizyphus mauritiana Lamk.) cv. Umran. Haryana J. Hort. Sci. 30 (3-4): 161-64

Singh., Sanjay., Brahmachari, V. S. and Jha, K. K. 1998. Effect of calcium and polythene wrapping on storage life of mango. Indian J. Hort. 55(3): 218-222.

*Singh, B. P, Singh, H. K and Chauhan, K. S. 1981. Effect of post-harvest calcium treatments on the storage life of guava fruits. Indian Journal of Agricultural Science. 51(1):44-47.

Soppin R., Jyothi, M. H. and Ekbote S. 1997a. Effect of chemicals and growth regulations on physico-chemical characters of storage behaviour of guava (Psidium guajava L.) fruit cv. Sardar. Advances in Agricultural Research in India. 8: 1-7

Sudha, R., Ponnuswami, V. and Kavino, M. 2006. Efficacy of pre- and post-harvest chemical treatments on physical characteristics of sapota. Crop. Res. Hisar. 32(2): 179-82.

Yadav., Subhash., Shukla, H. S. and Ram, R. A. 2010. Studies on foliar application of NAA, $\mathrm{GA}_{3}$, boric acid and $\mathrm{Ca}\left(\mathrm{NO}_{3}\right)_{2}$ on fruit retention, growth, yield and quality of aonla (Emblica officinalis Gaertn.) cv. Banarasi. Hort J. 23(2):

Ziao, Yan Huang., Jianchang., Li Hongbin., Xiao, Y., Hung, J. C. and Li, H. B. 1998. Effect of pre-harvest spraying calcium and NAA on storage of strawberry. China Fruits, 2: 24-25.

\section{How to cite this article:}

Vani. N. U., A. Bhagwan, A. Kiran Kumar and Sreedhar. M.. 2020. Effect of Pre Harvest Spray of Different Forms of Calcium on Post-Harvest Quality of Guava cv. Allahabad Safeda. Int.J.Curr.Microbiol.App.Sci. 9(07): 197-209. doi: https://doi.org/10.20546/ijcmas.2020.907.023 